\title{
Behavioral and biological responses of black bean aphid (Aphis fabae, Scopoli, 1763) on seven Algerian local broad bean cultivars
}

\author{
Fouad MERADSI $^{1 *}$ and Malik LAAMARI ${ }^{1}$
}

Received June 30, 2017; accepted November 04, 2018.

Delo je prispelo 30.junija 2017, sprejeto 04. novembra 2018.

\begin{abstract}
We studied the behavioral and biological parameters of Aphis fabae (Homoptera: Aphididae, Scopoli, 1763) on seven local Vicia faba L. cultivars. The antixenosis was conducted under laboratory controlled conditions of the temperature, light regime and relative humidity $\left(18 \pm 0.25{ }^{\circ} \mathrm{C}\right.$; L16: D8; $37.5 \pm$ $0.6 \%)$ for test in light, and $\left(19^{\circ} \mathrm{C} ; 42 \%\right.$ relative humidity) for test in dark. The least preferred host plants for attractivity was the cultivar 141 in both tests while the cultivar 145 was the most preferred in light test, and the cultivar 107 in dark test. The antibiotic experiment was conducted also under laboratory conditions (L16: D8 photoperiod, $17 \pm 1{ }^{\circ} \mathrm{C}$, and $43.5 \pm 5 \% \mathrm{r}$. h.). Antibiosis was determined by studying the pre-reproductive period, reproductive period, adult longevity, survival, daily and total fecundity. The analysis of variance indicated that no significant differences on pre-reproductive period and daily fecundity of the A. fabae among the cultivars. However, the longest times of reproductive period, adult longevity, and survival were recorded on cultivar 135 followed by cultivar 141. The highest (85.8) and the lowest (15.8) number of progeny were observed on 135 and 141 cultivars, respectively.
\end{abstract}

Key words: Aphis fabae; antibiosis; antixenosis; cultivar; resistance; Vicia faba $\mathrm{L}$.
IZVLEČEK

OBNAŠALNI IN BIOLOŠKI ODZIVI ČRNE FIŽOLOVE UŠI (Aphis fabae Scopoli, 1763) NA SEDEM ALŽIRSKIH SORT BOBA

Preučevani so bili obnašalni in biološki parametri črne fižolove uši (Aphis fabae Scopoli, 1763, Homoptera: Aphididae) na sedem lokalnih sort boba (Vicia faba L.). Poskusi antiksenoze so bili izvedeni v nadzorovanih laboratorijskih temperaturnih, vlažnostnih in svetlobnih razmerah, $18 \pm 0.25{ }^{\circ} \mathrm{C}$; dan 16 ur, noč 8 ur in $37,5 \pm 0,6 \%$ relativni zračni vlagi za poskuse na svetlem in pri $19{ }^{\circ} \mathrm{C}$ in $42 \%$ relativni zračni vlagi za poskuse $\mathrm{v}$ temi. Najmanj priljubljena gostiteljska rastlina glede privlačnosti je bila $\mathrm{v}$ obeh poskusih sorta 141 , medtem, ko je bila pri poskusih na svetlem preferirana sorta 145 in pri poskusih v temi sorta 107. Tudi poskusi $\mathrm{z}$ antibiozo so bili izvedeni $\mathrm{v}$ laboratorijskih razmerah (dan 16 ur, noč 8 ur, pri temperaturi $17 \pm 1{ }^{\circ} \mathrm{C}$ in pri $43,5 \pm 5 \%$ relativni zračni vlagi. Antibiotični učinki so bili določeni $\mathrm{s}$ preučevanjem predreproduktivnega obdobja, reproduktivnega obdobja, dolžine življenske dobe imagov, njihovim preživetjem in dnevno ter celokupno plodnostjo. Analiza variance je pokazala, da glede na sorto boba ni bilo značilnih razlik $\mathrm{v}$ dolžini predreprokcijskega obdobja in dnevne plodnosti uši. Najdaljše reproduktivno obdobje, največja življenska doba imagov in največje preživetje uši je bilo zabeleženo na sorti 135 in nato na sorti 141. Največje $(85,8)$ in najmanjše $(15,8)$ število potomcev je bilo opaženo na sortah 135 in 141.

Ključne besede: Aphis fabae; antibioza; antiksenoza; sorta; odpornost; Vicia faba L.

\section{INTRODUCTION}

Broad bean, Vicia faba L., is one of the oldest cultivated field crop. It constitutes a major protein source for human population in many countries (Laudadio et al., 2011). The black bean aphid, Aphis fabae Scopoli, 1763
(Homoptera: Aphididae) is the most destructive insect pest of broad bean in Algeria. In Algeria, broad bean production includes highly diversified local cultivars. About 68 local cultivars, have been identified by

1 Laboratory of Improvement of the Phytosanitary Protection Techniques in Mountainous Agrosystems, Aureses Region. Agronomy Department, Institute of veterinary and Agricultural sciences, Batna 1 University (05000), Batna, Algeria; *corresponding author: fouadmeradsi@gmail.com or fouad.entomo@yahoo.fr 
morphological and agronomic characterization (Meradsi, 2009).

The black bean aphid is one of the 14 aphid species of most agricultural importance in the worldwide (Blackman \& Eastop, 2007). A. fabae is a very polyphagous species, but the actual host range of the aphid that colonizes beans and sugar beet is unclear, because it is a number of a bewildering complex of species, at least some of which also have wide host ranges (Blackman \& Eastop, 2007). A. fabae has a wide distributional range. It occurs in Europe, Western Asia, Arab countries particularly Jordan (Mustafa \& Qasem, 1984), Africa, and South America. It is a vector of more than 30 plant viruses, including non-persistent viruses of bean and peas, beets, crucifers, cucurbits, Dahlia, potato, tomato, and tulip, and the persistent beet yellow net virus and potato leaf roll virus (Blackman \& Eastop, 2007).

Insects are usually controlled by insecticides. However, the excessive use of insecticides to control these pests can have a negative financial and environmental consequences, including the development of high levels of resistance to conventional insecticides (Ogendo et al., 2003), the high costs of synthetic pesticides and associated toxicity risks (Mihale et al., 2009), the destruction of beneficial insects (pollinators, parasitoids and predators), pesticide residue magnification in humans and wildlife and disruption of ecosystem (Ruchika \& Kumar, 2012). Accordingly, the need to search for alternative insect control methods has been increased.

Host plant resistance has been used as a control measure for various agricultural pests for many years (Smith, 2005). Plant resistance may be the most effective, economical, and environmentally sound management tactic to control A. fabae in crops. Some progress has been archived in screening broad bean cultivars against black bean aphid and a number of cultivars have been identified as possible source of resistance for breeding programs (El-Dafrawi et al., 1991; Laamari et al., 2008; Meradsi \& Laamari, 2016a, 2016b, 2016c; Meradsi, 2017).

Smith (2005) indicated three general categories of plant resistance to insects, which have become widely accepted by entomologists: non preference or, antixenosis, tolerance, and antibiosis. Antixenosis is one of the most important category of plant resistance to aphids on broad bean as well as antibiosis and tolerance of plants to insects. Antixenosis and non-preference denote the presence of morphological or chemical plant factors that adversely alter arthropod behavior, resulting in the selection of an alternate host plant. Physical barriers such as thickened plant epidermal layers, waxy deposits on leaves, stems, or fruits, or a change in the density of trichomes (plant hairs) on normally susceptible plants may force arthropods to abandon their efforts to consume, ingest or oviposit on an otherwise palatable plant (Smith, 2005). The antibiotic effects of a resistant plant range from mild to lethal, and may result from both chemical and morphological plant defensive factors. Lethal effects may be acute, in which case they often affect young larvae and eggs. The chronic effects of antibiosis often lead to mortality in older larvae and prepupae that fail to pupate, and in pupae and adults which fail to eclose. Individuals surviving the direct effects of antibiosis may also suffer the debilitating effects of reduced body size and mass, prolonged periods of development in the immature stages, and reduced fecundity (Smith, 2005).

In the present study, the modalities of the antixenotic and antibiotic resistance were used to determine the most resistant cultivars among seven local broad bean cultivars for the black bean aphid.

\section{MATERIALS AND METHODS}

\subsection{Plant}

Broad bean cultivars used in this study were selected on the basis of field evaluation for their resistance to $A$. fabae (Meradsi, 2009). They included seven cultivars: Six resistant cultivars $(12,111,126,135,141$, and 145) and one highly susceptible cultivar (107). Seeds of the broad bean cultivars were acquired from Plant Protection laboratory of Batna (in the east of Algeria).

The (Table 1) showed the agronomical characteristics of the seven broad bean cultivars used in this study. 
Table 1: Agronomical characteristics of seven broad bean cultivars used to study of the resistance to the black bean aphid, Aphis fabae

\begin{tabular}{ccccccccccccccc}
\hline Cultivar & Origin & \multicolumn{10}{c}{ Agronomical characteristics } \\
\cline { 3 - 14 } & & 3 & 4 & 6 & 9 & 10 & 13 & 15 & 21 & 23 & 24 & 27 & 31 \\
\hline 12 & Biskra & 25.84 & 2.60 & $\mathrm{p}$ & 4.53 & 2.34 & 3 & 3.28 & 4.17 & 13.12 & 2.5 & 2.83 & 1.11 \\
11 & Biskra & 27.17 & 2.50 & $\mathrm{p}$ & 5.05 & 2.43 & 3.50 & 3.30 & 3.37 & 12.33 & 2.30 & 1.13 & 0.87 \\
126 & Biskra & 28.08 & 2.75 & $\mathrm{p}$ & 4.98 & 2.29 & 2.50 & 2.71 & 5.43 & 13.33 & 2.27 & 1.50 & 0.85 \\
135 & Khenchela & 20.08 & 2.50 & $\mathrm{p}$ & 4.75 & 2.22 & 2.40 & 3.06 & 3.33 & 10.63 & 2.58 & 3.80 & 0.86 \\
141 & Biskra & 27.13 & 2.50 & $\mathrm{p}$ & 6.36 & 3.35 & 1.5 & 3.17 & 7 & 10.50 & 2.70 & 0.75 & 0.31 \\
145 & Khenchela & 25.53 & 3.67 & $\mathrm{p}$ & 5.07 & 2.17 & 2 & 3.30 & 7.67 & 11 & 2.60 & 1.33 & 0.92 \\
107 & Biskra & 33.16 & 4.80 & $\mathrm{p}$ & 5 & 2.83 & 3.80 & 3.46 & 11.6 & 11.4 & 3.4 & 0.8 & 1.53 \\
\hline
\end{tabular}

Notes. Biskra: in the south of Algeria, Khenchela: in the east of Algeria, 3: plant: height (cm), 4: plant : number of stems (including tillers more than half the length of the main stem), 6: stem: anthocyanin coloration (p: present), 9: leaflet: length (basal pair of leaflet at secondary node, $\mathrm{cm}$ ), 10: leaflet width (basal pair of leaflet at secondary node, $\mathrm{cm}), 13$ : raceme: number of flowers, 15: flower: length $(\mathrm{cm}), 21$ : truss: number of pods, 23: pod: length (without beak, $\mathrm{cm}$ ), 24: pod: width (from suture to suture, $\mathrm{cm}$ ), 27: pod: number of ovules (including seeds), 31: dry seed: mass (g).

\subsection{Insects}

The aphids used for this study were obtained from a single winged adult of $A$. fabae. The adult aphid was collected in early October 2008 from culture of the broad bean plants in field of the Batna region (in the east of Algeria). the single winged adult was reared on broad bean seedlings under greenhouse conditions $[6 \pm$ $4{ }^{\circ} \mathrm{C}, 93 \pm 7 \%$ relative humidity and a photoperiod of 14: 10 (L: D) h].

\subsection{Antixenosis}

Antixenosis against aphid was evaluated by allowing aphids a free choice between plants of similar growth stage (Castro et al., 2005), second leaf fully expanded, 12 growth stage (Mier, 2001), each planted in a pot $(6.5 \mathrm{~cm}$ diameter $\times 8 \mathrm{~cm}$ height $)$, one plant of every cultivar tested was randomly placed in a circle, with their leaves directed towards the center of the circle (Castro et al., 1999; 2001). Twenty-eight adult aphids, equivalent to four aphids per plant (Budak et al., 1999), were placed in the lid of a Petri dish $(5.7 \mathrm{~cm}$ diameter). After $2 \mathrm{~h}$ the number of adult aphids on each plant was recorded, and this was repeated $24 \mathrm{~h}, 26 \mathrm{~h}, 48 \mathrm{~h}$, and 72 $\mathrm{h}$ later.
Only the adult aphids were recorded because nymphs were not involved in the host selection process (Budak et al., 1999). This experiment was conducted under laboratory conditions of the temperature, light regime and humidity $\left(18 \pm 0.25{ }^{\circ} \mathrm{C}\right.$; L16 : D8; $37.5 \pm 0.5 \%$ relative rumidity).

The same experiment was repeated under the dark (Hesler \& Tharp, 2005) with $\left(19{ }^{\circ} \mathrm{C} ; 42 \%\right.$ relative humidity). After $24 \mathrm{~h}$ the number of adults on each plant was recorded.

\subsection{Antibiosis}

The antibiotic test was conducted under laboratory controlled conditions at L16 : D8 photoperiod, $17 \pm$ $1{ }^{\circ} \mathrm{C}$, and $43.5 \pm 5 \%$ relative humidity. The test was assessed using eight plants for each cultivar (one plant per pot) and the experiment was conducted according to simple randomized block design. Two apterous adults were placed on each plant at 11 growth stage (Mier, 2001), and allowed to deposit nymphs. After 24 h, we removed the adults and all offspring but one nymph (first larval stage) from each plant. Pre-reproductive period, reproductive period, adult longevity, survival, daily and total fecundity were determined.

\subsection{Statistical analysis}

Data concerning all counts of antixenosis (in the tow experiments; light and dark), pre-reproductive period, reproductive period, adult longevity, survival, daily and total fecundity of the aphid on the broad bean cultivars were compared using analysis of variance (ANOVA). When the ANOVA demonstrated significant differences, the means were separated using the Tukey's test at $\mathrm{P} \leq 0.05$. The experiments were arranged in the randomized complete block design (RCBD). All statistical analyses were performed with IBM SPSS statistical software (Version 23.0.0.0) (SPSS, 2015). 


\section{RESULTS AND DISCUSSION}

\subsection{Antixenosis}

\subsubsection{Test in light}

Significant antixenosis effect $(\mathrm{P}<0.05)$ against of $A$. fabae was found in the seven cultivars of broad bean for $24 \mathrm{~h}, 26 \mathrm{~h}$, and $48 \mathrm{~h}$ (Table 2). Aphids on 145 were generally found to have the highest antixenosis level (6 adults per plant), while those on 141 were found to be (0.4 adults per plant) (Table 2$)$.

\subsubsection{Test in dark}

The results indicated significant differences $\left(\mathrm{F}_{2.57}=\right.$ 3.017; $\mathrm{P}=0.028$ ) (Table 2) among cultivars. It was highest on cultivar 107 (5 adults per plant) and ranged from 0.75 to 2.25 adults per plant for the six other cultivars (Table 2 ).

Table 2: Number of Aphis fabae (Mean $\pm \mathrm{SE}$ ) on seven broad bean cultivars

\begin{tabular}{ccccccc}
\hline Cultivar & \multicolumn{5}{c}{ Light tests } & Dark test \\
\cline { 2 - 7 } & $2 \mathrm{~h}$ & $24 \mathrm{~h}$ & $26 \mathrm{~h}$ & $48 \mathrm{~h}$ & $72 \mathrm{~h}$ & $24 \mathrm{~h}$ \\
\hline 12 & $4 \pm 1,87 \mathrm{a}$ & $4.6 \pm 1.63 \mathrm{ab}$ & $4.6 \pm 1.63 \mathrm{ab}$ & $4.8 \pm 1.59 \mathrm{~b}$ & $4.2 \pm 1.24 \mathrm{a}$ & $0.75 \pm 0.48 \mathrm{a}$ \\
107 & $3.6 \pm 2.06 \mathrm{a}$ & $4 \pm 2.02 \mathrm{ab}$ & $3.8 \pm 1.98 \mathrm{ab}$ & $38 \pm 1.98 \mathrm{ab}$ & $3.8 \pm 1.98 \mathrm{a}$ & $5 \pm 1.22 \mathrm{~b}$ \\
111 & $0.6 \pm 0.4 \mathrm{a}$ & $0.6 \pm 0.4 \mathrm{a}$ & $0.6 \pm 0.4 \mathrm{a}$ & $0.6 \pm 0.4 \mathrm{a}$ & $0.6 \pm 0.4 \mathrm{a}$ & $1.5 \pm 0.29 \mathrm{a}$ \\
126 & $1.4 \pm 0.68 \mathrm{a}$ & $1.4 \pm 0.68 \mathrm{a}$ & $1.4 \pm 0.68 \mathrm{a}$ & $1.4 \pm 0.68 \mathrm{ab}$ & $1.4 \pm 0.68 \mathrm{a}$ & $0.75 \pm 0.48 \mathrm{a}$ \\
135 & $2.6 \pm 1.54 \mathrm{a}$ & $2 \pm 1.55 \mathrm{ab}$ & $2.2 \pm 1.5 \mathrm{ab}$ & $2.2 \pm 1.5 \mathrm{ab}$ & $2.4 \pm 1.5 \mathrm{a}$ & $2.25 \pm 1.31 \mathrm{a}$ \\
141 & $0.4 \pm 0.24 \mathrm{a}$ & $0.4 \pm 0.24 \mathrm{a}$ & $0.4 \pm 0.24 \mathrm{a}$ & $0.4 \pm 0.24 \mathrm{a}$ & $0.4 \pm 0.24 \mathrm{a}$ & $1.5 \pm 0.96 \mathrm{a}$ \\
145 & $5.2 \pm 1.93 \mathrm{a}$ & $6 \pm 1.67 \mathrm{~b}$ & $5.4 \pm 1.5 \mathrm{~b}$ & $5.4 \pm 1.5 \mathrm{~b}$ & $5.4 \pm 1.5 \mathrm{a}$ & $1.75 \pm 0.48 \mathrm{a}$ \\
$\mathrm{N}$ & 5 & 5 & 5 & 5 & 5 & 4 \\
$\mathrm{~F}$ & 1.60 & 2.59 & 2.454 & 2.455 & 2.42 & 3.01 \\
$\mathrm{P}$ & $0.183(\mathrm{~ns})$ & $0.040^{*}$ & $0.049^{*}$ & $0.049^{*}$ & $0.052(\mathrm{~ns})$ & $0.028^{*}$ \\
\hline
\end{tabular}

Means within a column followed by the same letter do not differ significantly. N: number of repetitions, ns: not significant, (ANOVA: * $\mathrm{P} \leq 0.05$; Tukey's test).

Antixenotic resistance observed against black bean aphid have resulted from multiple factors such as plant morphology (shape and size), pigmentation of assay and chemical defenses.

During the first test (in light) the cultivar 145 was the favorite of the insect while the cultivar 141 was the last choice with 111 and 126. However, in second test (in obscurity) the susceptible control 107 was the first choice of adults than the other cultivars.

The comparison of both tests showed that the morphology or color of plant (assay) or the both had a high part in the selection of A. fabae for 145 and 12 cultivars, because the attraction of this cultivars was high in light (6 and 4.6 adults per plant in mean) and low in dark (1.75 and 0.75 adults per plant in mean) for the tow cultivars respectively. The susceptible control 107 was favorite in both tests (probably has a high concentration of attractive volatiles substances). The cultivars 126, 111 and 141 were least preferred by the apterous adults of A. fabae in both tests, probably they had likely a high content of repulsive volatiles substances. The cultivar 135 has an intermediate attraction for both tests. In the study of the preference of seven varieties of wheat by the RWA, Lage et al. (2004) had indicated that the resistant cultivar attract only 2.1 adults and the susceptible cultivar attract 5.2 adults.
Sandanayaka et al. (2005) noted the mean percentage settlement of 25 first instar wolly apple aphid nymphs Eriosoma lanigerum (Hausmann, 1802) on 13 apple accessions, the results showed that the percentage settlement was the highest $(41.08 \%)$ on RG and the lowest $(3.76 \%)$ on $\mathrm{G}$.

Several factors were responsible for the selection of the host plant such as volatile substances. Webster et al. (2008) identified fifteen electrophysiologically active compounds of broad bean ('Sutton Dwarf') to winged A. fabae. In the field, A. fabae lands preferentially on yellow leaves (Bernays \& Chapman, 1994). Two other works about the pea aphid, Acyrthosiphon pisum Harris, 1776. In the first, on the alfalfa, Medicago sativa L., Golawska et al. (2008) indicated that the resistant cultivar Radius had a higher level of saponins and a lower level of flavonoids than the susceptible cultivgar Sapko. In the second work, on European lupine, Lupinus angustifolius L., Kordan et al. (2008) noted that also the resistance cultivar ('Juno') contained a higher concentration of lupanine $\left(0.59 \mu \mathrm{g} \mathrm{g}^{-1}\right.$ dry matter $)$ than the susceptible cultivar (Markiz) $\left(0.51 \mu \mathrm{g} \mathrm{g}^{-1}\right.$ dry matter). Cai et al. (2004) reported that the resistant cultivar of wheat KOK1679 to the grain aphid Sitobion avenae Fabricius, 1794 had high indole alkaloids content during vegetative growth. Several studies at the order of Lepidoptera were determined the substances 
responsible on the oviposition of females. For examples, the presence of n-alkanes on corn, Zea mays L. (Udayagiri \& Mason, 1997), the 2-tridecanone on Lycopersicon spp. (Maluf et al., 1997), the malic acid with a concentration from 0.1 to $0.7 \mu \mathrm{mol} \mathrm{cm} \mathrm{cm}^{-2}$ on chickpea, Cicer arietinum L. (Yoshida et al., 1997) and rutin and genistin on soy bean (Piubelli et al., 2005).

Morris et al. (2009) isolated three diterpinoid acids, grandifloric acid (1), 15ß-hydroxy-ent-trachyloban-19oic acid (2), and 17- hydroxy-16 $\alpha$-ent-kauran-19-oic acid (3), from polar fractions of pre-bloom sunflower head extracts, as oviposition stimulants for the banded sunflower moth Cochylis hospes (Walsingham, 1884) Johnson et al. (2008) indicated that the resistant cultivar Nadine of potato has a high content of glucoalkaloids (309.33 mg kg${ }^{-1}$ dry mass) than the susceptible cultivar Marfona (96.90 mg kg-1 dry mass). Chemical analysis of the host plant leaves of Gonioctena linnaeana Schrank, 1781, Salix triandra L. showed that quantities but not quality of the phenolic compounds influenced the feeding of the $G$. linnaeana larva. The two most important compounds were gallocatechin and salidroside (Neimi et al., 2005). Leiss et al. (2009) recorded that the thrips-resistant in Senecio hybrids contained higher amounts of the pyrrolizidine alkaloids (PA), jacobine and jaconine, especially in younger leaves.

\subsection{Antibiosis}

Cultivars showed no significant effects on prereproductive period $(\mathrm{F}=1.41 ; \mathrm{df}=2.45 ; \mathrm{P}=0.243)$ or daily fecundity per female $(\mathrm{F}=1.20$; df $=2.45 ; \mathrm{P}=$ 0.331 ) (Table 3). The statistical analysis of reproductive period, adult longevity, survival, and total fecundity showed a high significant difference $(\mathrm{P}<0.001)$ (Table $3)$. Reproductive period, adult longevity, and survival were the longest on $135(19 ; 21.2$; and 27.6 days respectively), and the lowest on 141 (3.2; 3.4; and 11 days respectively) (Table 3 ). However, number of total offspring per female of A. fabae was the highest on 135 (85.8 nymphs) and the smallest on 141 (15.8) (Table 3).

Table 3: Biological parameters (Mean \pm SE) of Aphis fabae on seven broad bean cultivars $(n=5)$

\begin{tabular}{ccccccc}
\hline Cultivar & $\begin{array}{c}\text { Pre-reproductive } \\
\text { period }\end{array}$ & $\begin{array}{c}\text { reproductive } \\
\text { period }\end{array}$ & $\begin{array}{c}\text { Adult } \\
\text { longevity }\end{array}$ & Survival & $\begin{array}{c}\text { Daily } \\
\text { fecundity }\end{array}$ & $\begin{array}{c}\text { Total } \\
\text { fecundity }\end{array}$ \\
\hline 126 & $7.4 \pm 0.24 \mathrm{a}$ & $3.4 \pm 1.17 \mathrm{ab}$ & $4.2 \pm 1.24 \mathrm{a}$ & $10.8 \pm 1.11 \mathrm{a}$ & $5.67 \pm 0.43 \mathrm{a}$ & $19.6 \pm 7.03 \mathrm{a}$ \\
12 & $8.4 \pm 0.4 \mathrm{a}$ & $3.8 \pm 1.32 \mathrm{ab}$ & $4.2 \pm 1.5 \mathrm{a}$ & $12.2 \pm 1.24 \mathrm{a}$ & $5.26 \pm 0.83 \mathrm{a}$ & $17.0 \pm 3.17 \mathrm{a}$ \\
107 & $7.4 \pm 0.24 \mathrm{a}$ & $6.6 \pm 2.13 \mathrm{ab}$ & $6.8 \pm 2,39 \mathrm{a}$ & $13.8 \pm 2.39 \mathrm{a}$ & $6.01 \pm 0.85 \mathrm{a}$ & $38.8 \pm 12.49 \mathrm{ab}$ \\
135 & $7.6 \pm 0.24 \mathrm{a}$ & $19.0 \pm 2.14 \mathrm{c}$ & $21.2 \pm 2.73 \mathrm{~b}$ & $27.6 \pm 2.67 \mathrm{~b}$ & $4.62 \pm 0.27 \mathrm{a}$ & $85.8 \pm 5.91 \mathrm{c}$ \\
141 & $8.0 \pm 0.0 \mathrm{a}$ & $3.2 \pm 0.2 \mathrm{a}$ & $3.4 \pm 0.24 \mathrm{a}$ & $11.0 \pm 0.0 \mathrm{a}$ & $4.9 \pm 0.41 \mathrm{a}$ & $15.8 \pm 1.93 \mathrm{a}$ \\
145 & $7.6 \pm 0.4 \mathrm{a}$ & $8.2 \pm 1.91 \mathrm{~b}$ & $8.8 \pm 1.8 \mathrm{a}$ & $15.4 \pm 1.83 \mathrm{a}$ & $6.18 \pm 0.78 \mathrm{a}$ & $47.6 \pm 10.45 \mathrm{~b}$ \\
111 & $7.8 \pm 0.37 \mathrm{a}$ & $4.2 \pm 0.49$ & $4.2 \pm 0.5 \mathrm{a}$ & $11.8 \pm 0.86 \mathrm{a}$ & $6.37 \pm 0.34 \mathrm{a}$ & $26.8 \pm 3.35 \mathrm{ab}$ \\
$\mathrm{P}$ & 0.243 & $0.000^{*}$ & $0.000^{*}$ & $0.000^{*}$ & 0.331 & $0.000^{*}$ \\
$\mathrm{~F}$ & 1.417 & 13.774 & 13.621 & 12.460 & 1.209 & 11.652 \\
df & 2.45 & 2.45 & 2.45 & 2.45 & 2.45 & 2.45 \\
\hline
\end{tabular}

Means within a column followed by the same letter do not differ significantly (Duncan's test, $\mathrm{P}<0.05$ ). ${ }^{*} \mathrm{P}<0.001$.

In the present study, the effect of cultivars on the prereproductive period was absent. In contrast, several works showed that this effect was present, for example, the green peach aphid Myzus persicae (Sulzer, 1776) on spinach, Spinacia oleracea L. (Mcleod et al., 1991), the cotton aphid, Aphis gossypii Glover, 1877on chrysanthemum and cucumber (Storer \& van Emden, 1995; van Steenis \& El-Khawass, 1995), the bird cherry-oat aphid Rhopalosiphum padi (Linnaeus, 1758) on wheat and triticale (Hesler \& Tharp, 2005), the greenbug Schizaphis graminum (Rondani, 1852) on wheat (Castro et al., 2001), and the pea aphid Acyrthosiphon pisum on alfalfa, Medicago sativa (Golawska et al., 2008). Also, Guillaume \& Boissot (2001) observed that the resistant cultivar of melon was prolonged the larval development of the melonworm Diaphania hyalinata (Linnaeus, 1767) to 17.08 days that the susceptible cultivar (12.57 days). Other study showed that the days to adult emergence of bruchid
Zabrotes subfasciatus (Boheman, 1833) was 50.3 on resistant cultivar of common bean Phaseolus vulgaris 'SMARC1-PN1' and 33 on susceptible cultivar 'SMARC4N-PN' (Hartweck et al., 1997).

The present experiment demonstrated the greater effect of the cultivar 135 on reproductive period and adult longevity of A. fabae. However, these parameters were six times longer than the cultivar 141. The total fecundity on the cultivar 135 was 5.4 times higher than the cultivar 141. Indeed, Klinger et al. (1998) reported that the reproductive period of A. gossypii was 21.5 days on susceptible cotton cultivar PMR5 and 13.5 days on the resistant cultivar AR5. The total fecundity was twice on susceptible cultivar in comparison with the resistant cultivar (Formusoh et al., 1994). Wearing et al. (2003b) indicated that the percentage of the larval survival of the brownheaded leafroller, Ctenopseustis obliquana (Walker, 1863) after three weeks on the 
resistant apple cultivar was $6.4 \%$ and $81.5 \%$ on the susceptible cultivar. Wearing et al. (2003a) noted that the survival of larvae to pupation was $64 \%$ on the resistant apple cultivar Nevis 1 and $100 \%$ on the susceptible cultivar Mother to lightbrown apple moth, Epiphyas postvittana (Walker, 1863) at $20^{\circ} \mathrm{C}$.

The secondary metabolites were important for the life of the insects. Wilkinson \& Douglas (2003) reported that one or more of the eight clones of A. fabae tested displayed depressed larval survival, larval growth rate, on diets lacking histidine, methionine, threonine, and valine. Other study noted by Bastide et al. (1988) indicated that the phenolic extracts of young peach leaves influenced the survival and the mass of the nymphs of M. persicae. Dried alfalfa (Medicago sativa) leaf tissue incorporated in artificial diet to give a final concentration of 0.5 or $1.6 \mathrm{mg} \mathrm{g}^{-1}$ fresh mass of saponins significantly inhibited growth and development of larvae of the European corn borer,
Ostrinia nubilalis (Hubner, 1796) (Nozzolillo et al., 1997). Ulmer \& Dosdall (2006) indicated that high levels of specific glucosinolates such as $p$ hydroxybenzyl and 3-butenyl glucosinolate were associated with increased developmental time or reduced mass of the cabbage speedpod weevil, Ceutorhynchus obstrictus (Marshham, 1802) in Brassicaceae species.

The constitutive activity of phenylalanine ammonialyase (PAL), polyphenol oxidase (PPO), and peroxidase (POD) in resistant and susceptible wheat cultivars against cereal aphid Sitobion avenae at various developmental stages, tillering, stem elongation, flag leaf, and ear was analyzed by Han et al. (2009), the results showed that the PAL and POD in resistant cultivars exhibited greater activity than susceptible ones at the tillering, stem elongation, and flag leaf stages. The PPO had a higher activity in the resistant cultivars at all developmental stages.

\section{CONCLUSIONS}

These preliminary data suggest that among the seven cultivars tested in this study, the mediocre performance of the black bean aphid was noted on the cultivars 141 . But, the best performances of $A$. fabae were found on the cultivar 135 . The present study revealed that cultivar 141 had an insecticidal propriety against A. fabae and could be employed as alternative for chemical pesticides.

\section{ACKNOWLEDGEMENTS}

The authors thank Salim LEBBAL for excellent help.

\section{REFERENCES}

Bastide, P., Massonie, G., \& Macheix, J. J. (1988). Influence in vitro des composés phénoliques des jeunes feuilles du pêcher, Prunus persica (L.) Batsch, sur le puceron vert du pêcher, Myzus persicae Sulzer. Agronomie, 8(9), 787-792. doi:10.1051/agro:19880905

Bernays, E. A., \& Chapman, R. F. (1994). Host-Plant Selection by Phytophagous Insects. New York, Chapman \& Hall. doi:10.1007/b102508

Blackman, R. L., Eastop, V. F. (2007). Taxonomic issues. In H. F. van Emden \& R. Harrington (Eds.), Aphids as Crop Pests (pp. 1-29). U. K., CABI Millennium. doi:10.1079/9780851998190.0001

Budak, S., Quisenberry, S.S., \& Ni, X. (1999). Comparison of Diuraphis noxia resistance in wheat isolines and plant introduction lines. Entomologia Experimentalis et Applicata, 92, 157-164. doi:10.1046/j.1570-7458.1999.00535.x
Cai, Q. N., Zhang, Q. W., \& Cheo, M. (2004). Contribution of indole alkaloids to Sitobion avenae (F.) resistance in wheat. Journal of Entomology and Nematology, 128(8), 517-521.

Castro, A. M., Ramos, S., Vasicek, A., Worland, A., Giménez, D., Clúa, A. A., \& Suárez, E. (2001). Identification of wheat chromosomes involved with different types of resistance against greenbug (Schizaphis graminum, Rond.) and the Russian wheat aphid (Diuraphis noxia, Mordvilko). Euphytica, 118, 321-330. doi:10.1023/A:1017503828952

Castro, A. M., Vasicek, A., Manifiesto, M., Giménez, D. O., Tacaliti, M. S., Dobrovolskaya, O., Röder, M. S., Snape, J. W., \& Börner, A. (2005). Mapping antixenosis genes on chromosome $6 \mathrm{~A}$ of wheat to greenbug and to a new biotype of Russian wheat 
aphid. Plant Breeding, 124, 229-233. doi:10.1111/j.1439-0523.2005.01082.x

Castro, A. M., Vasicek, A., Ramos, S., Worland, A., Suárez, E., Muňoz, M., Giménez, D., \& Clúa, A. A. (1999). Different types of resistance against greenbug, Schizaphis graminum Rond, and the Russian wheat aphid, Diuraphis noxia Mordvilko, in wheat. Plant breeding, 118, 131-137. doi:10.1046/j.1439-0523.1999.118002131.x

El-Defrawi, G, El-Gantiry, A. M., Weigand, S., Khalil, S. A. (1991). Screening of faba bean (Vicia faba L.) for resistance to Aphis craccivora Koch. Arab Journal of Plant Protection, 9(2), 138-141.

Formusoh, E. S., Wilde, G. E., Hatchett, J. H., \& Collins, R. D. (1994). Resistance to the Russian Wheat Aphid (Homoptera: Aphididae) in WheatRelated Hybrids. Journal of Economic Entomology, 87(1), 241-244. doi:10.1093/jee/87.1.241

Golawska, S., Lukasik, L., \& Leszczynski, B. (2008). Effect of alfalfa saponins and flavonoids on pea aphid. Entomologia Experimentalis et Applicata, 128, 147-153. doi:10.1111/j.15707458.2008.00709.x

Guillaume, R., \& Boissot, N. (2001). Resistance to Diaphania hyalinata (Lepidoptera: Crambidae) in Cucumis Species. Journal of Economic Entomology, 94(3), 719-723. doi:10.1603/00220493-94.3.719

Han, Y., Wang, Y., Bi, J. L., Yang, X. Q., Huang, Y., Zhao, X., ... Cai, Q. N. (2009). Constitutive and Induced Activities of Defense-Related Enzymes in Aphid-Resistant and Aphid-Susceptible Cultivars of Wheat. Journal of Chemical Ecology, 35(2), 176-182. doi:10.1007/s10886-009-9589-5

Hartweck, L. M., Cardona, C., \& Osborn, T. C. (1997). Bruchid resistance of common bean lines having an altered seed protein composition. Theoretical and Applied Genetics, 95, 1018-1023. doi:10.1007/s001220050656

Hesler, L. S., \& Tharp, C. I. (2005). Antibiosis and antixenosis to Rhopalosiphum padi among triticale accessions. Euphytica, 143, 153-160. doi:10.1007/s10681-005-3060-7

Johnson, S. N., Anderson, E. A., Dawson, G., \& Griffiths, D. W. (2008). Varietal susceptibility of potatoes to wireworm herbivory. Agricultural and Forest Entomology, 10, 167-174. doi:10.1111/j.1461-9563.2008.00372.x

Klingler, J., Powell, G., Thompson, G. A., \& Isaacs, R. (1998). Phloem specific aphid resistance in Cucumis melo line AR5: effects on feeding behaviour and performance of Aphis gossypii.
Entomologia Experimentalis et Applicata, 86, 7988. doi:10.1046/j.1570-7458.1998.00267.x

Kordan, B., Gabryś, B., Dancewicz, K., Lahuta, L. B., Piotrowicz-Cieślak, A., \& Rowińska, E. (2008). European yellow lupine, Lupinus luteus, and narrow-leaf lupine, Lupinus angustifolius, as hosts for the pea aphid, Acyrthosiphon pisum. Entomologia Experimentalis et Applicata, 128, 139-146. doi:10.1111/j.1570-7458.2008.00702.x

Laamari, M., Khelfa, L., \& Coeur d'Acier, A. (2008). Resistance source to cowpea aphid (Aphis craccivora Koch) in broad bean (Vicia faba L.) Algerian landrace collection. African Journal of biotechnology, 7(14), 2486-2490.

Lage, J., Skovmand, B., \& Andersen, S. B. (2004). Resistance categories of synthetic hexaploid wheats resistant to the Russian wheat aphid (Diuraphis noxia). Euphytica, 136, 291-296. doi:10.1023/B:EUPH.0000032732.53350.93

Laudadio V., Ceci E., \& Tufarelli V. (2011). Productive traits and meat fatty acid profile of broiler chicken fed diets containing micronized fava beans (Vicia faba L. var. minor) as the main protein source. Journal of Applied Poultry Research, 20, 12-20. doi:10.3382/japr.2010-00173

Leiss, K. A., Choi, Y. H., Abdel-Farid, I. B., Verpoorte, R., \& Klinkhamer, P. G. L. (2009). NMR Metabolomics of Thrips (Frankliniella occidentalis) Resistance in Senecio Hybrids. Journal of Chemical Ecology, 35(2), 219-229. doi:10.1007/s10886-008-9586-0

Maluf, W. R., Barbosa, L. V., \& Costa Santa-Cecília, L. V. (1997). 2-Tridecanone-mediatedmechanisms of resistance to the South American tomato pinworm Scrobipalpuloides absoluta (Meyrick, 1917) (Lepidoptera-Gelechiidae) in Lycopersicon spp. Euphytica, 93, doi:10.1023/A:1002963623325

McLeod, P., Morelock, T. E., \& Goode, M. J. (1991). Prefernce, Developmental Time, Adulte Longivity and Fecundity of Green Peach Aphid (Homoptera: Aphididae) on Spinach. Journal of Entomological Science, 26(1), 95-98. doi:10.18474/0749-800426.1 .95

Meradsi, F. (2009). Contribution à l'étude de la résistance naturelle de la fève Vicia faba L. au puceron noir Aphis fabae Scopoli, 1763 (Homoptera: Aphididae). Mémoire de Magister. Protection des végétaux. Université Batna 1.

Meradsi, F. (2017). Natural resistance of broad bean against the Black bean aphid. Origin and 
catogories of the resistance. Germany, LAP: Lambert Academic Publishing. ICS Morebooks.

Meradsi, F., \& Laamari, M. (2016a). Genetic resource of the resistance of Vicia faba L. against the black bean aphid, Aphis fabae Scopoli. Journal of Agricultural Studies, 4(2), 107-114. doi:10.5296/jas.v4i2.9333

Meradsi, F., \& Laamari, M. (2016b). Population dynamics and biological parameters of Aphis fabae Scopoli on five broad bean cultivars. International Journal of Biosciences, 9(2), 58-68. doi:10.12692/ijb/9.2.58-68

Meradsi, F., \& Laamari M. (2016c). Aphicidal and behavioral effects of Vicia faba L. (Fabales: Fabaceae) leaf extracts against Aphis fabae Scopoli (Hom., Aphididae). Jordan Journal of Agricultural Sciences, 12(4), 1085-1094. doi:10.12816/0035070

Mier, U. (2001). Growth stages of mono-and dicotyledonous plants. $B B C H$ Monograph. Germany: Federal Biological Research Centre for Agriculture and Forestry.

Mihale, M. J., Deng, A. L., Selemani, H. O., MugishaKamatenesi, M., Kidukuli, A. W., \& Ogendo, J. O. (2009). Use of Indigenous knowledge in the management of field and storage pests around Lake Victoria basin in Tanzania. African Journal of Environmental Science and Technology, 3(9), 251259.

Morris, B. D., Charlet, L. D., \& Foster, S. P. (2009). Isolation of three Diterpenoid Acids from Sunflowers, as Oviposition Stimulants for the Banded Sunflowers Moth, Cochylis hospes. Journal of Chemical Ecology, 35(1), 50-57. doi:10.1007/s10886-008-9567-3

Mustafa, T. M., \& Qasem, J. R. (1984). Host ranges of the bean aphid Aphis fabae in Jordan. Entomologica Basiliensia, 9, 48-53.

Niemi, L., Wennström, A., \& Ericson, L. (2005). Insect feeding preferences and plant phenolic glucosides in the system Gonioctena linnaeana - Salix triandra. Entomologia Experimentalis et Applicata, 115, 61-66. doi:10.1111/j.1570-7458.2005.00269.x

Nozzolillo, C., Arnason, J. T., Campos, F., Donskov, N., \& Jurzysta M. (1997). Alfalfa leaf saponins and insect resistance. Journal of Chemical Ecology, 23(4), doi:10.1023/B:JOEC.0000006384.60488.94

Ogendo, J. O., Belmain, S. R., Deng, A. L., \& Walker, D. J. (2003). Comparison of toxic and repellent effects of Lantana camara L. with Tephrosia vogelii hook and a synthetic pesticide against Sitophilus zeamais Motschulsky (Coleoptera:
Curculionidae) in stored maize grain. Insect science and its Application, 23(2), 127-135. doi:10.1017/S1742758400020348

Piubelli, G. C., Hoffmann-Campo, C. B., Moscardi, F., Miyakubo, S. H., \& Neves de Oliveira, M. C. (2005). Are chemical compounds important for soybean resistance to Anticarsia gemmatalis? Journal of Chemical Ecology, 31, 1509-1525. doi:10.1007/s10886-005-5794-Z

Ruchika, K., \& Kumar D. (2012). Occurrence and infestation level of sucking pests: Aphids on various host plants in agricultural fields of Vadora, Gujarat (India). International Journal of Scientific and Research Publications, 2(7), 1-6.

Sandanayaka, W. R. M., Bus, V. G. M., \& Connolly, P. (2005). Mechanisms of woolly aphid [Eriosoma lanigerum (Hausm.)] resistance in apple. Journal of Applied Entomology, 129, 534-541. doi:10.1111/j.1439-0418.2005.01004.x

Smith, C. M. (2005). Plant resistance to arthropods: Molecular and conventional approaches. Berlin Heidelberg New York: Springer. doi:10.1007/14020-3702-3

Storer, J. R., \& van Emden, H. F. (1995). Antibiosis and antixenosis of chrysanthemum cultivars to the aphid Aphis gossypii. Entomologia Experimentalis et Applicata, 77, 307-314. doi:10.1111/j.15707458.1995.tb02328.x

SPSS, Inc. 2015. SPSS for Windows. Version 23.0.0.0. Chicago, Illinois.

Udayagiri, S., \& Mason, C. E. (1997). Epicuticular wax chemicals in Zea mays influence oviposition in Ostrinia nubilalis. Journal of Chemical Ecology, 23 , 1675-1687. doi:10.1023/B:JOEC.0000006443.72203.f7

Ulmer, B. J., \& Dosdall, L. M. (2006). Glucosinolate profile and oviposition behavior in relation to the susceptibilities of Brassicaceae to the cabbage seedpod weevil. Entomologia Experimentalis et Applicata, 121, 203-213. doi:10.1111/j.15708703.2006.00480.x

van Steenis, M. J., \& E1-Khawass, K. A. M. H. (1995). Life history of Aphis gossypii on cucumber: influence of temperature, host plant and parasitism. Entomologia Experimentalis et Applicata, 76, 121131. doi:10.1111/j.1570-7458.1995.tb01954.x

Wearing, C. H., Colhoun, K., Attfield, B., Marshall, R.R., \& McLaren, G. F. (2003a). Screening for resistance in apple cultivars to lightbrown apple moth, Epiphyas postvittana, and greenheaded leafroller, Planotortrix octo, and its relationship to field damage. Entomologia Experimentalis et 
Applicata, $\quad 109, \quad 39-53 . \quad$ doi:10.1046/j.15707458.2003.00091.x

Wearing, C. H., Colhoun, K., McLaren, G. F., Attfield, B., \& Bus, V. G. M. (2003b). Evidence for single gene resistance in apple to brownheaded leafroller, Ctenopseustis obliquana, and implications for resistance to other New Zealand leafrollers. Entomologia Experimentalis et Applicata, 108, 110. doi:10.1046/j.1570-7458.2003.00062.x

Webster, B., Bruce, T., Dufour, S., Birkemeyer, C., Birkett, M., Hardie, J., \& Pickett, J. (2008). Identification of Volatile Compounds Used in Host Location by the Black Bean Aphid, Aphis fabae.
Journal of Chemical Ecology, 34(9), 1153-1161. doi:10.1007/s10886-008-9510-7

Wilkinson, T. L., \& Douglas, A. E. (2003). Phloem amino acids and the host plant range of the polyphagous aphid, Aphis fabae. Entomologia Experimentalis et Applicata, 106, 103-113. doi:10.1046/j.1570-7458.2003.00014.x

Yoshida, M., Cowgill, S. E., \& Wightman, J.A. (1997). Roles of oxalic and malic acids in chickpea trichome exudate in host-plant resistance. Journal of Chemical Ecology, 23, 1195-1210. doi:10.1023/B:JOEC.0000006395.45516.e8 